\title{
Does Traditional Feeding of Outdoor Guard Dogs Provide a Food Resource for Wild Mammals and Birds?
}

\author{
Róża Andrzejczak ${ }^{1,2}{ }^{\text {, }}$ Łukasz Dylewski ${ }^{3}\left(\mathbb{D}\right.$, Leszek Jerzak ${ }^{2} \mathbb{D}$, Branislav Pet'ko $^{1,4}$ and Lukasz Myczko $^{1, *(\mathbb{D})}$ \\ 1 Department of Zoology, Poznań University of Life Sciences, Wojska Polskiego 71 C, 60-625 Poznań, Poland; \\ roza.andrzejczak@wp.pl (R.A.); brano.petko@gmail.com (B.P.) \\ 2 Institute of Biological Scienes, University of Zielona Góra, 65-516 Zielona Góra, Poland; \\ 1.jerzak@wnb.uz.zgora.pl \\ 3 Institute of Dendrology, Polish Academy of Sciences, Parkowa 5, 62-035 Kórnik, Poland; \\ dylewski91@gmail.com \\ 4 University of Veterinary Medicine in Kosice, Komenského 68/73, 04181 Košice, Slovakia \\ * Correspondence: lukasz.myczko@up.poznan.pl
}

check for

updates

Citation: Andrzejczak, R.; Dylewski, Ł.; Jerzak, L.; Pet'ko, B.; Myczko, Ł. Does Traditional Feeding of Outdoor Guard Dogs Provide a Food Resource for Wild Mammals and Birds? Animals 2021, 11, 1198. https://doi.org/ 10.3390/ani11051198

Received: 19 March 2021

Accepted: 19 April 2021

Published: 22 April 2021

Publisher's Note: MDPI stays neutral with regard to jurisdictional claims in published maps and institutional affiliations.

Copyright: (c) 2021 by the authors. Licensee MDPI, Basel, Switzerland. This article is an open access article distributed under the terms and conditions of the Creative Commons Attribution (CC BY) license (https:// creativecommons.org/licenses/by/ $4.0 /)$.
Simple Summary: Access to food is crucial in the life of birds, and affects reproduction, survival and, consequently, population size. We investigated how traditional care of dogs affected rural birds and other animal populations. Using camera traps, it was found that the food fed to dogs was also taken by seven species of birds and at least three species of mammals. The most numerous species taking dog food was the house sparrow, Passer domesticus, which is declining in Europe. In the case of this species, females were more likely than males to use food provided for dogs, with a clear preference for food prepared in the human kitchen. We conclude that the food provided to domestic pets can be an important component of the diet of wild birds and mammals living close to humans.

Abstract: Access to food is crucial in the life of birds and affects reproduction, survival and, consequently, population size. In the case of bird species inhabiting villages, poorer food conditions now exist, mainly because of changes in the lifestyle of rural residents and a reduction in the number of farm animals traditionally housed in backyards. Recent changes have also affected dog populations in villages, and the majority of them are no longer kept outside as guard dogs, but rather inside houses as pets. We investigated how traditional care of dogs impacted rural birds and other animal populations. The study was carried out at the end of winter and early spring in 29 farmsteads in western Poland. Using camera traps, it was found that the food fed to dogs was also taken by seven species of birds and at least three species of mammals. The most numerous species taking dog food was the house sparrow, Passer domesticus, which is declining in Europe. In the case of this species, females were more likely than males to use food given to dogs, with a clear preference for food prepared in the human kitchen. We conclude that the food provided to domestic pets can be an important component of the diet of wild birds and mammals living close to humans.

Keywords: traditional food sources; farmland; pets; villages

\section{Introduction}

Birds in farmland are declining across Europe, and one of the main reasons is decreasing food resources resulting from the intensification of agriculture [1-3]. However, in Central Europe, the population size of birds in farmland is generally higher due to less-intensive agriculture [3,4], but also from the presence of refugia for many species in agricultural holdings, both in the breeding season [5], and throughout the year [6]. To date, research has focused on the roles of plant food sources; weeds on the outskirts of the village, and the remains of grain provided for poultry have been stressed [7]. Rural backyards were identified as being particularly important at the end of winter [8], when the availability of natural food sources is very limited, primarily as a result of the consumption 
of the best food sources [7]. The end of winter and the beginning of spring are the periods when birds replenish their energy resources which are necessary to start reproduction [9]. Therefore, accessing food during this period should involve the use of various available food resources. For example, feeding birds in gardens and yards is very common in villages and benefits many bird species [10]. But wild birds not only use food sources provided intentionally by humans, but also those provided unintentionally such as leftover feed provided to farm animals and waste food $[7,10]$. One example of the latter is food provided by farmers and owners to farm guard dogs [11]. The pattern of feeding dogs in villages has changed a lot recently and instead of food from the owner's kitchen, more are fed with commercial food [12,13]. Moreover, due to sociological changes in villages [5,14], dogs are more often now typical pets, living in houses, rather than traditional guard animals [11]. Pet food is changing to have a greater proportion of plant ingredients, with a potentially visible impact on the environment [15]. However, Okin [15] did not discuss the link between dog food and wild animals. Obviously, birds foraging in farmyards will also try to use food provided for dogs. Therefore, the main aim of the current study was to describe the number of wild species of birds and mammals accessing food provided for dogs. In order to estimate the extent of this phenomenon and identify which species of birds and mammals were involved, our study took place in the critical period at the end of winter and in early spring. To avoid problems with species identification and the potential impact on wild animals (e.g., their behaviour, especially vigilance etc.) we decided to conduct the study in a non-invasive way using camera traps which have become popular in the study of the use of space by animals $[16,17]$. Videos from camera traps allowed us also to investigate the behaviour of wild animals using the food of guard dogs. Due to limits of population size, we decided to conduct a fuller analysis of the house sparrow, Passer domesticus, which has declined throughout Europe, partly due to lack of food, [18-21]. Additionally, we analyzed the influence of dog behaviour on the probability of house sparrow foraging. We predicted that aggressive behaviour of dogs would be treated by birds as a danger signal and would potentially negatively influence the probability of a visit [22]. Moreover, we expected that the response of birds to different dog behaviour, i.e., reaction or lack of reaction by feeding birds, would also be influenced by the sex of the bird [23].

\section{Material and Methods}

\subsection{Fieldwork}

The study was conducted in rural areas in western Poland, mainly in the vicinity of Poznań ( $\left.52^{\circ} 24^{\prime} \mathrm{N}, 16^{\circ} 55^{\prime} \mathrm{E}\right)$. In total, 29 locations were selected where guard dogs were kept outside the property, and where owners regularly provided them with food and water. To avoid pseudo-replication, study locations were spaced apart by at least $1 \mathrm{~km}$. Field work was carried out at the end of winter and early spring, i.e., at a critical period of availability of natural food sources for many farmland birds [6,9], from mid-February to the beginning of April 2016. At each location we set a Bushnell Camera Trap (NatureView HD Live View model No 119740), $1.5 \mathrm{~m}$ from, and aimed at, the dog food and water bowls. At each location the camera was installed for $24 \mathrm{~h}$. Videos were initiated by a motion sensor and consisted of $30 \mathrm{~s}$ of movie with $1 \mathrm{~s}$ intervals [24]. The following parameters were collected at all locations: date, geographical coordinates, type of food fed to animals (purchased, home-prepared). Records were made of the type of bowl used by the observed animal (food bowl, water bowl), the place from where food was taken (bowl, food scattered), place of consumption (on the spot, taken away), and the species of the observed animal. In the case of house sparrows we determined the sex of the bird. We noted the dog's reaction towards the animal taking its food if he ran to the bowl. We considered the dog reacted if it showed aggression more than once to animals taking food. 


\subsection{Statistical Analysis}

We used a generalized linear mixed model (GLMM) with a negative binomial distribution to test the number of house sparrow visits compared to the type of supplementary resources, hereafter food type (home prepared food, purchased and water), sex (male or female), dog reaction (no-reaction, reaction). Additionally, we added the following interactions: food type $\times$ sex, food type $\times$ dog reaction and sex $\times$ dog reaction. We included location as a random factor. We used a least squares mean contrast with the Tukey method to compare between significant factor levels. For type of food, chi square contingency tests were used to compare the total numbers of visits between female and male house sparrow. All analyses were carried out in the R 3.3.2 statistical environment [25] using lme4 [26], lsmeans [27] and ggplot2 [28] packages.

\section{Results}

Wild animals were observed accessing dog food in 21 (72.4\%) of the 29 locations. In total, 1818 visits by wild species were noted and in 1755 (96.5\%) of these either food or water was taken. The mean $( \pm \mathrm{SE})$ number of visits per [non-zero] location was $83.6 \pm 23.6$. Dog food was taken by wild animals on 1630 visits and water on 125 visits.

During the study, we recorded the use of dog food by seven species of birds (see Table 1) and at least three species of mammals including Red Fox Vulpes vulpes, Beech Marten Martes foina and mainly unidentified rodents. Most rodent recordings were night time recordings of small rodents lacking in characteristic features, thus we were not able to determine these to species level. However, recorded rodents included adult brown rats Rattus norvegicus. In other recordings young brown rats were likely candidates, but we cannot exclude the possibility of another rodent species (most likely house mouse Mus musculus or wood mouse Apodemus sylvaticus), and thus we decided to treat all rodents as a single group.

Table 1. Numbers of visits and frequency of feeding visits by wild animals recorded at 21 of 29 locations during $24 \mathrm{~h}$ monitoring. Species are arranged by descending frequency.

\begin{tabular}{ccccc}
\hline \multirow{2}{*}{ Species } & \multicolumn{3}{c}{ Number of Visits } & \multirow{2}{*}{ Frequency [\%] of Feeding Visits } \\
\cline { 2 - 4 } & Total & without Feeding & with Feeding & 87.4 \\
\hline House Sparrow Passer domesticus & 1584 & 51 & 1533 & 6.5 \\
Magpie Pica pica & 122 & 8 & 114 & 3.6 \\
Rodents & 66 & 2 & 64 & 1.5 \\
Tree Sparrow Passer montanus & 28 & 1 & 27 & 0.3 \\
Collared Dove Streptopelia decaocto & 5 & 0 & 5 & 0.3 \\
Great Tit Parus major & 5 & 0 & 5 & 0.2 \\
Red Fox Vulpes vulpes & 3 & 0 & 3 & 0.1 \\
Feral Pigeon Columba liviaf. urbana & 2 & 0 & 2 & 0.1 \\
Jay Garrulus glandarius & 2 & 1 & 1 & 0.1 \\
Beech Marten Martes foina & 1 & 0 & 1 & 100.0 \\
\hline
\end{tabular}

Recordings were dominated by house sparrow visits, comprising over $87 \%$ of all observed animals using dog food or water. For this reason, the more detailed analysis is focused only on this species. Out of 1584 recorded house sparrows visits, 898 (56.7\%) were by females, and $686(43.3 \%)$ by males (Table 2, Figure 1 ).

Table 2. The number of female and male house sparrow visits between the three food categories.

\begin{tabular}{ccccc}
\hline Category & Female & Male & $\chi^{2}$ & $p$ \\
\hline Home prepared food & 681 & 536 & 17.28 & $<0.001$ \\
Dog food & 134 & 66 & 23.12 & $<0.001$ \\
Water & 57 & 59 & 0.034 & 0.853 \\
\hline
\end{tabular}



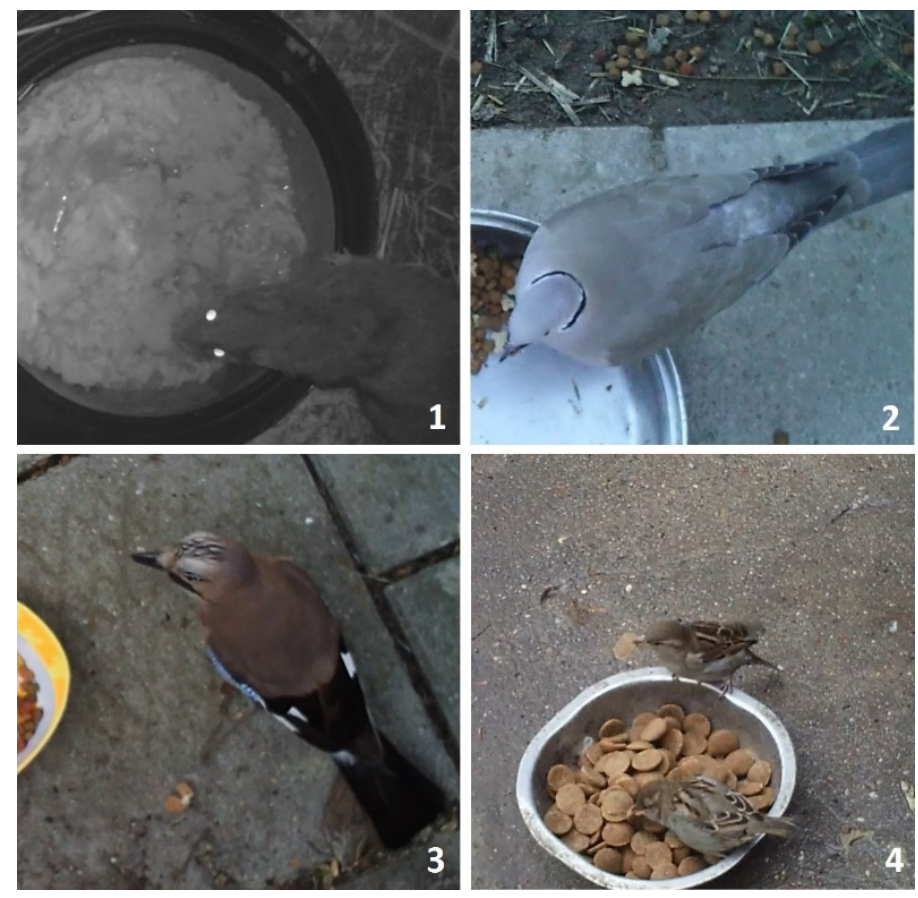

Figure 1. Examples of wild animals recorded with camera traps. (1) Brown rat Rattus norvegicus, (2) Collared dove Streptopelia decaocto, (3) Jay Garrulus glandarius, (4) female house sparrows Passer domesticus.

Based on the simple Chi square test, female house sparrow visits were significantly more frequent at home prepared food and dog food than male visits, but water intake by female and male house sparrows did not differ significantly. However, the GLMM showed that only the type of food (Wald $\chi^{2} 11.47, \mathrm{df}=2, p=0.003$ ) significantly influenced the number of house sparrow visits (Table 3 ). Thus, based on the more conservative model which includes other variables and interactions, as well as the random effect, we did not find any significant difference between male and female visits. However, this model is based on the observed sex ratio of visits during our study and does not assume an equal sex ratio in the house sparrow population.

Table 3. Results of the generalized linear mixed model with a negative binomial distribution.

\begin{tabular}{cccc}
\hline Variables & Wald $\chi^{\mathbf{2}}$ & df & $p$ \\
\hline Food type & 11.47 & 2 & 0.003 \\
Sex & 0.08 & 1 & 0.781 \\
Dog reaction & 2.38 & 1 & 0.123 \\
Food type $\times$ Sex & 0.91 & 2 & 0.634 \\
Food type $\times$ Dog reaction & 3.59 & 2 & 0.166 \\
Sex $\times$ Dog reaction & 0.06 & 1 & 0.812 \\
\hline
\end{tabular}

The number of visits was significantly higher when home prepared food was provided (mean \pm SE $45.07 \pm 9.73)$ than purchased dog food $(9.35 \pm 2.34)$ or water $(6.44 \pm 1.48)$ (Figure 2). 


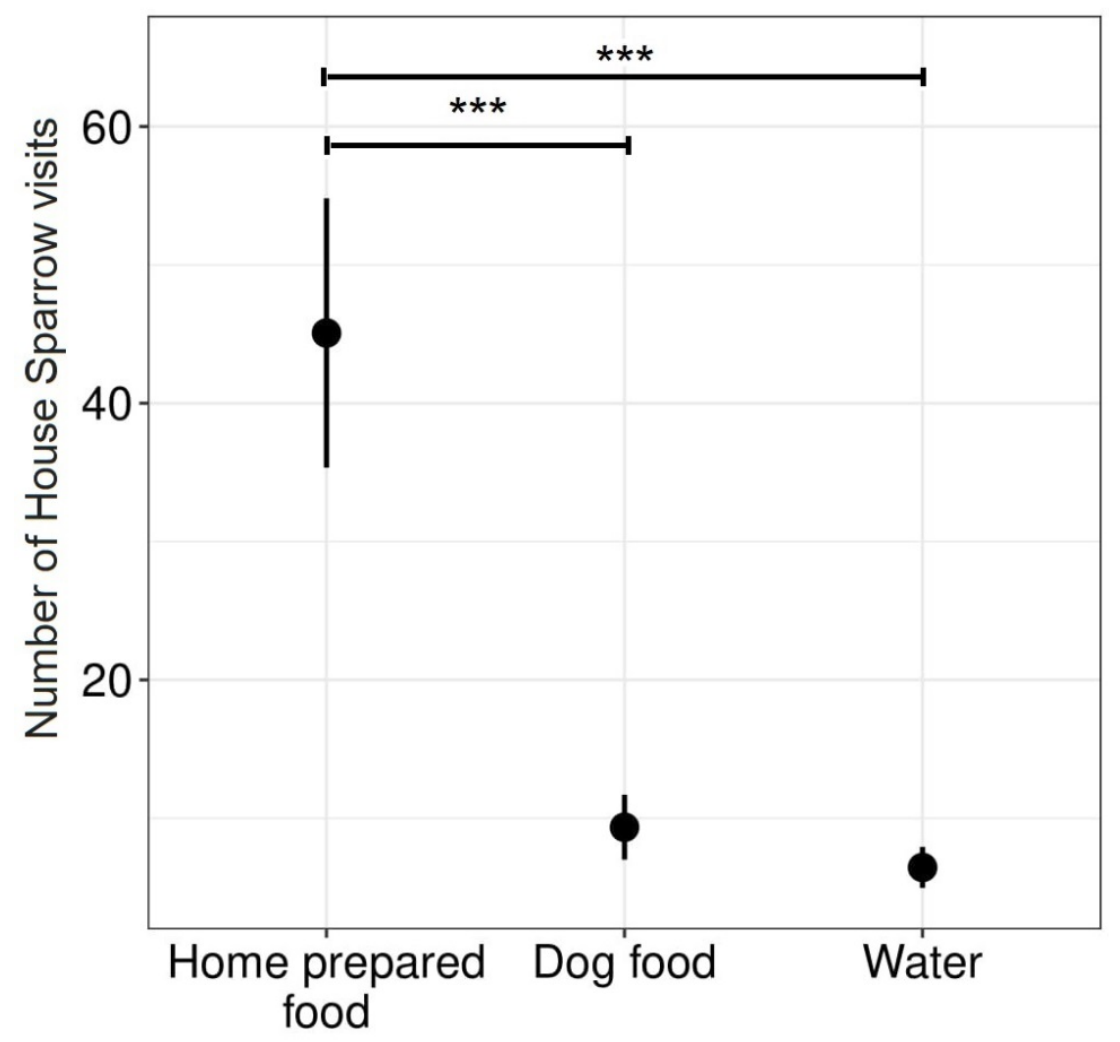

\section{Supplementary resources}

Figure 2. The mean \pm standard error (SE) number of house sparrow visits per location to supplementary resources: home-prepared food, purchased dog food and water. ${ }^{* * *}$ indicates a significant difference at $p<0.001$.

\section{Discussion}

Our results clearly show that the food provided for outdoor dogs is commonly used as a food resource by wild animals. We recorded feeding visits by wild animals of food or water intended for dogs in more than $70 \%$ of our study locations where dogs were fed outdoors. In combination with the large number of wild animal visits (see Table 1) this shows the importance of this resource for some species of wild animals. Species taking food and, less often, water are typical bird and mammal species living in Polish villages [5,29]. Most recorded visits were by the house sparrow. This synanthropic species is declining in Europe [18-20] and is unable to survive in the European environment unless in coexistence with human settlements $[19,21]$. This strong dependence of house sparrow populations is mostly based on artificial food resources generated by humans. However, current changes in housing of farm animals and in land use drastically limit the food resources available to house sparrows $[30,31]$. The traditional outdoor keeping and feeding of dogs is still popular in central and eastern Europe. They now provide one of the few remaining and predictable sources of human generated waste food in human settlements in the rural environment. This is different from the situation with most bird feeders, where food is often available less regularly, and mainly during harsh winters [10]. If this way of feeding dogs in Central Europe changes, this food source for the house sparrow will disappear and local extinctions of house sparrows should be expected. In England, the disappearance of overwinter food sources has been shown to be the cause for local population extinctions in rural habitats [18].

The time of year in which we monitored the activity of wild animals visiting dog feeding places is critical, especially for females building up body resources for the forthcoming breeding season. During this period, female sparrows collect additional energy resources 
in preparation for egg laying [32,33]. This is confirmed by a different use of food and water and is underlined by the significant difference in the number of visits between male and female house sparrows, despite the expected sex ratio balance in the population [34]. The second bird species regularly using the dog food was the magpie Pica pica. It is well known that this corvid uses artificial food sources in human settlements [35]. The frequency of magpie visits indicate that dog food is an important and well-used resource for this species allowing it to survive the winter in good condition.

In contrast to bird visits, which can be considered as neutral or even as positive by some dog owners, rodent visits would rather be considered as a negative phenomenon. Rodent access to dog food occurs relatively often, and these resources can increase the reproduction rates of the brown rat, considered a most onerous pest.

However, each contact of wild animals with pets may contribute to the transfer of pathogens, especially if the faeces and secretions of wild animals reach the dogs' food. Reported cases of pathogen transfer concern both wild birds to pets $[36,37]$ and possible transfers from wild mammals to pets [38]. Wild animals visiting dog food dishes increases the probability of disease spreading, since it is the number of contacts of different individuals of wild animals that increase disease probability. House sparrows can transmit salmonellae [39], and the large numbers of recorded visits of this species during the current research suggests the possibility of relatively frequent transmission. Comparison of these findings with additional studies, focused on the Campylobacter species [40-42] suggest a more complicated situation. Firstly the dog dishes can stimulate the spread of pathogens between birds similar to bird feeders [42], secondly the dogs can be the source and reservoir from which wild animals become infected, especially since the reported prevalence of the Campylobacter species in dog populations is high [40,41].

\section{Conclusions}

The large number of wild animal visits shows the importance of dog food for some species of wild animal, especially house sparrows. The significant difference in the number of visits between male and female house sparrows suggests a critical role for females building up body resources for the forthcoming breeding season i.e., collecting additional energy resources in preparation for egg laying. For the house sparrow, which has declined throughout Europe, access to dog food is probably critical for the survival of local populations.

Wild animals strongly preferred home-produced food rather than commercial dog food. This is interesting, because the production and use of commercial dog food, especially in developed countries, is increasing greatly $[12,15]$. Changes in the pattern of dog feeding are probably one further example of how human-generated food waste has affected bird numbers and behaviour [15], although it is probably only important at a local scale. On the other hand, taking account of global changes to the structure of villages, for example rather less associated with traditional farming but rather more as a dormitory settlement for city workers $[3,5,14,43]$, our results may suggest a more general, even global, picture.

As far as we are aware, this is the first study directly focused on this aspect, and before calculating the real environmental costs linked to changes in food production for pets (see [12]) more research is necessary. The recorded visits also increase the possibilities of pathogen transfer between wild animals and dogs, although at this stage this is mostly a speculative discussion.

Author Contributions: R.A. performed the experiments, wrote the paper; writing-review and editing, prepared and analysed data, contributed substantial materials; Ł.D. performed statistical analysis; B.P. wrote the paper; writing-review and editing; L.J. wrote the paper; writing-review and editing; Ł.M. supervised the project, developed the ideas, developed and designed methods, wrote the paper; writing - review and editing. All authors have read and agreed to the published version of the manuscript.

Funding: Research was supported by the statutory funding No. 506. 511.09.00 of the Faculty of Veterinary Medicine and Animal Science Poznan University of Life Sciences, Poland; Department of Zoology. This research received no external funding. 
Institutional Review Board Statement: Not applicable.

Informed Consent Statement: Ethical review and approval were waived for this study, due to only passive observation using. No ethics approval either within national or EU legal systems was needed. This work was carried out in accordance with the Polish law (Article 52, paragraph 2 of Nature Conservation Act).

Data Availability Statement: The data presented in this study are available on request from the corresponding author. The data are not publicly available due to privacy reasons.

Acknowledgments: We would like to thank the owners of the properties and dogs without whom we could not have conducted the research, Tim Sparks and Piotr Tryjanowski for valuable comments to the first version of the MS.

Conflicts of Interest: The authors declare no conflict of interest.

\section{References}

1. Donald, P.F.; Green, R.E.; Heath, M.F. Agricultural intensification and the collapse of Europe's farmland bird populations. Proc. R. Soc. Lond. B Biol. 2001, 268, 25-29. [CrossRef]

2. Reif, J.; Vermouzek, Z. Collapse of farmland bird populations in an Eastern European country following its EU accession. Conserv. Lett. 2019, 12, e12585. [CrossRef]

3. Rosin, Z.M.; Hiron, M.; Żmihorski, M.; Szymański, P.; Tobolka, M.; Pärt, T. Reduced biodiversity in modernized villages: A conflict between sustainable development goals. J. Appl. Ecol. 2020, 57, 467-475. [CrossRef]

4. Tryjanowski, P.; Hartel, T.; Báldi, A.; Szymański, P.; Tobolka, M.; Herzon, I.; Goławski, A.; Konvička, M.; Hromada, M.; Jerzak, L.; et al. Conservation of farmland birds faces different challenges in Western and Central-Eastern Europe. Acta Ornithol. 2011, 46, 1-12. [CrossRef]

5. Rosin, Z.M.; Skórka, P.; Pärt, T.; Żmihorski, M.; Ekner-Grzyb, A.; Kwieciński, Z.; Tryjanowski, P. Villages and their old farmsteads are hot spots of bird diversity in agricultural landscapes. J. Appl. Ecol. 2016, 53, 1363-1372. [CrossRef]

6. Š́álek, M.; Bažant, M.; Żmihorski, M. Active farmsteads are year-round strongholds for farmland birds. J. Appl. Ecol. 2018, 55, 1908-1918. [CrossRef]

7. S Š́lek, M.; Havlíček, J.; Riegert, J.; Nešpor, M.; Fuchs, R.; Kipson, M. Winter density and habitat preferences of three declining granivorous farmland birds: The importance of the keeping of poultry and dairy farms. J. Nat. Conserv. 2015, 24, 10-16. [CrossRef]

8. Goławski, A.; Dombrowski, A. The effects of weather conditions on the numbers of wintering birds and the diversity of their assemblages in villages and crop fields in east-central Poland. Ital. J. Zool. 2011, 78, 364-369. [CrossRef]

9. Siriwardena, G.M.; Calbrade, N.A.; Vickery, J.A. Farmland birds and late winter food: Does seed supply fail to meet demand? IBIS 2008, 150, 585-595. [CrossRef]

10. Tryjanowski, P.; Skórka, P.; Sparks, T.H.; Biaduń, W.; Brauze, T.; Hetmański, T.; Matryka, P.; Indykiewicz, P.; Myczko, Ł.; Kunysz, P.; et al. Urban and rural habitats differ in number and type of bird feeders and in bird species consuming supplementary food. Environ. Sci. Pollut. R. 2015, 22, 15097-15103. [CrossRef]

11. Serpell, J. (Ed.) The Domestic Dog; Cambridge University Press: Cambridge, UK, 2016; ISBN 9781139161800. [CrossRef]

12. Dodd, S.A.; Cave, N.J.; Adolphe, J.L.; Shoveller, A.K.; Verbrugghe, A. Plant-based (vegan) diets for pets: A survey of pet owner attitudes and feeding practices. PLoS ONE 2019, 14, e0210806. [CrossRef] [PubMed]

13. Morelli, G.; Stefanutti, D.; Ricci, R.A. Survey among Dog and Cat Owners on Pet Food Storage and Preservation in the Households. Animals 2021, 11, 273. [CrossRef] [PubMed]

14. Śleszyński, P.; Wiśniewski, R.; Szejgiec-Kolenda, B. Demographic processes in Poland in the years 1946-2016 and their consequences for local development: Current state and research perspectives. Geogr. Pol. 2018, 91, 317-334. [CrossRef]

15. Okin, G.S. Environmental impacts of food consumption by dogs and cats. PLoS ONE 2017, 12, e0181301. [CrossRef] [PubMed]

16. Trolliet, F.; Huynen, M.C.; Vermeulen, C.; Hambuckers, A. Use of camera traps for wildlife studies. A review. Biotechnol. Agron. Soc. 2014, 18, 446 .

17. Randler, C.; Kalb, N. Distance and size matters: A comparison of six wildlife camera traps and their usefulness for wild birds. Ecol. Evol. 2018, 8, 7151-7163. [CrossRef] [PubMed]

18. Hole, D.G.; Whittingham, M.J.; Bradbury, R.B.; Anderson, G.Q.; Lee, P.L.; Wilson, J.D.; Krebs, J.R. Widespread local house-sparrow extinctions. Nature 2002, 418, 931. [CrossRef]

19. Summers-Smith, J.D. The decline of the House Sparrow: A review. Brit. Birds 2003, 96, 439-446.

20. Robinson, R.A.; Siriwardena, G.M.; Crick, H.Q. Size and trends of the House Sparrow Passer domesticus population in Great Britain. IBIS 2005, 147, 552-562. [CrossRef]

21. Skórka, P.; Sierpowska, K.; Haidt, A.; Myczko, Ł.; Ekner-Grzyb, A.; Rosin, Z.M.; Kwiecinski, Z.; Suchodolska, J.; Takacs, V.; Jankowiak, Ł.; et al. Habitat preferences of two sparrow species are modified by abundances of other birds in an urban environment. Curr. Zool. 2016, 62, 357-368. [CrossRef]

22. Cavalli, M.; Baladrón, A.V.; Isacch, J.P.; Biondi, L.M.; Bó, M.S. Differential risk perception of rural and urban Burrowing Owls exposed to humans and dogs. Behav. Process. 2016, 124, 60-65. [CrossRef] [PubMed] 
23. Vincze, E.; Papp, S.; Preiszner, B.; Seress, G.; Bókony, V.; Liker, A. Habituation to human disturbance is faster in urban than rural house sparrows. Behav. Ecol. 2016, 27, 1304-1313. [CrossRef]

24. Gilmore, R.O.; Adolph, K.E. Video can make behavioural science more reproducible. Nat. Hum. Behav. 2017, 1, s41562-017. [CrossRef] [PubMed]

25. R Core Team. R: A Language and Environment for Statistical Computing; R Foundation for Statistical Computing: Vienna, Austria, 2016. [CrossRef]

26. Bates, D.; Maechler, M.; Bolker, B.; Walker, S. Fitting Linear Mixed-Effects Models Using lme4. J. Stat. Softw. 2015, 67, 1-48. [CrossRef]

27. Wickham, H. ggplot2. WIRES Comput. Stat. 2011, 3, 180-185. [CrossRef]

28. Lenth, R.V. Using lsmeans. J. Stat. Softw. 2017, 69, 1-33. [CrossRef]

29. Krauze-Gryz, D.; Gryz, J.; Goszczyński, J. Predation by domestic cats in rural areas of central Poland: An assessment based on two methods. J. Zool. 2012, 288, 260-266. [CrossRef]

30. Kosicki, J.Z.; Sparks, T.H.; Tryjanowski, P. House sparrows benefit from the conservation of white storks. Naturwissenschaften 2007, 94, 412-415. [CrossRef]

31. Bengtson, S.A.; Eliasen, K.; Jacobsen, L.M.; Magnussen, E. Man-dependence of House Sparrows (Passer domesticus) in the Faroe Islands: Habitat patch characteristics as determinants of presence and numbers. In Dorete-Her Book: Being a Tribute to Dorete Bloch and to Faroese Nature; Faroe University Press: Tórshvan, Faroe Islands, 2010; ISBN 978-99918-65-30-0.

32. Pinowska, B. The effect of energy and building resources of females on the production of House Sparrow (Passer domesticus (L.)) populations. Ekol. Pol. 1979, 27, 363-396.

33. Chastel, O.; Lacroix, A.; Kersten, M. Pre-breeding energy requirements: Thyroid hormone, metabolism and the timing of reproduction in house sparrows Passer domesticus. J. Avian Biol. 2003, 34, 298-306. [CrossRef]

34. Husby, A.; Saether, B.E.; Jensen, H.; Ringsby, T.H. Causes and consequences of adaptive seasonal sex ratio variation in house sparrows. J. Anim. Ecol. 2006, 75, 1128-1139. [CrossRef] [PubMed]

35. Krystofkova, M.; Fousová, P.; Exnerová, A. Nestling diet of the Common Magpie (Pica pica) in urban and agricultural habitats. Ornis Fenn. 2011, 88, 138-146.

36. Giovannini, S.; Pewsner, M.; Hüssy, D.; Hächler, H.; Degiorgis, M.P.R.; Hirschheydt, J.V.; Origgi, F.C. Epidemic of salmonellosis in passerine birds in Switzerland with spillover to domestic cats. Vet. Pathol. 2013, 50, 597-606. [CrossRef] [PubMed]

37. Smith, O.M.; Snyder, W.E.; Owen, J.P. Are we overestimating risk of enteric pathogen spillover from wild birds to humans? Biol. Rev. 2020, 95, 652-679. [CrossRef] [PubMed]

38. Theimer, T.C.; Clayton, A.C.; Martinez, A.; Peterson, D.L.; Bergman, D.L. Visitation rate and behavior of urban mesocarnivores differs in the presence of two common anthropogenic food sources. Urban Ecosyst. 2015, 18, 895-906. [CrossRef]

39. Pinowska, B.; Chylinski, G.; Gondek, B. Studies on the transmitting of salmonellae by house sparrows (Passer domesticus L.) in the region of Zulawy. Pol. Ecol. Stud. 1976, 2, 113-121.

40. Olson, P.; Sandstedt, K. Campylobacter in the dog: A clinical and experimental study. Vet. Rec. 1987, 121, 99-101. [CrossRef]

41. Acke, E.; McGill, K.; Golden, O.; Jones, B.R.; Fanning, S.; Whyte, P. Prevalence of thermophilic Campylobacter species in household cats and dogs in Ireland. Vet. Rec. 2009, 164, 44-47. [CrossRef]

42. Tryjanowski, P.; Nowakowski, J.J.; Indykiewicz, P.; Andrzejewska, M.; Śpica, D.; Sandecki, R.; Mitrus, C.; Goławski, A.; Dulisz, B.; Dziarska, J.; et al. Campylobacter in wintering great tits Parus major in Poland. Environ. Sci. Pollut. R. 2020, 27, 7570-7577. [CrossRef]

43. Antrop, M. Landscape change and the urbanization process in Europe. Landsc. Urban Plan. 2004, 67, 9-26. [CrossRef] 